\title{
History in Novels and Memoirs: Alfons Vermeulen on Rural Congo (1899-1904)
}

\author{
Jan Vansina
}

\begin{abstract}
Alfons Vermeulen published a novel about his life in a Congo town as a trader in 1933 and also left drafts about the same subject for his memoirs when he died in 1965. This essay systematically compares both documents using the rules of evidence and concludes that although it does not appear to be so on the surface the novel distorts the evidence he adduces considerably more than the memoirs. At the same time though both documents are equally deeply affected by the spirit of the time of their composition. Hence the combined evidence of both documents together is not only richer but also more reliable than their separate use.
\end{abstract}

Résumé: Alfons Vermeulen publia un roman en 1933 au sujet de sa vie de commerçant dans un village du Congo. Il laissa également une ébauche de mémoires sur le même sujet lors de son décès en 1965. Cette étude applique la méthode historique aux deux documentset conclut que, quoiqu'il n'en il paraît pas à première vue, en fait le roman dénature les données historiques considérablement plus que ses mémoires. Mais l'esprit de leur époque (Zeitgeist) affecte cependant aussi profondément l'un et l'autre document. De ce chef l'utilisation conjointe des deux est non seulement plus riche mais aussi plus fiable que leur emploi séparé.

\section{Introduction}

Historians of Africa are well aware that there exists a plethora of historical fiction, such as novels, novelas, short stories, or plays about the colonial

History in Africa, Volume 39 (2012), pp. 123-142

Jan Vansina, formerly of the University of Wisconsin-Madison is an historian of Africa, especially Central Africa and author of about twenty-five books and many articles. His Being Colonized: The Kuba Experience in Rural Congo, 1880-1960 (Madison, The University of Wisconsin Press, 2010) provides a wider context for this essay. 
period and published during that period. Joseph Conrad's Heart of Darkness is merely one of the oldest and the most famous among them. The difficulty in using them to document any aspect of history is precisely that these sources are fictional and hence are not concerned with any historical truth or accuracy. In contrast booklength memoirs from that period are quite rare. Their numbers, however, increased by leaps and bounds in the later twentieth century onwards, mainly after the colonies became independent, and substantial numbers of former colonials felt free to write and publish theirs. By definition and in contrast to fiction, memoirs and reminiscences are supposed to describe what happened. They are eyewitness accounts and until recently such accounts were considered to be wholly trustworthy and first rate sources. Yet, unlike diaries, memoirs are not contemporary with the events they describe and that fact should never be overlooked. After all the career situation and the outlook of the author certainly changed significantly in the interim and the overall Zeitgeist may also have become quite different.

In contrast to the stark opposition of fictive/factual that I just drew, however, a recent study shows that the gap between supposedly fictional novels and factual memoirs is not as great as it was imagined. ${ }^{1}$ In consequence it has become quite clear that any a priori characterization of novels and their ilk as poor sources versus memoirs as rich ones are equally wrong. Rather each instance should be judged on its merits and the rules of evidence should be carefully applied to every source separately. To document this argument I present a single, albeit complex, case that involves one novel and one memoir both produced by the same author.

\section{History Disguised?}

It was only some thirty years ago that I first became aware of a novel called De pioniersdagen van Chicongo [Chicongo's pioneering days: a tale about the life of pioneers in the Congo] as a crucial source for early colonial Kuba history. ${ }^{2}$ By then the book had been available for over forty-five years and yet I had missed it ever since I compiled my first Kuba bibliography. There was a good excuse for my ignorance: this work was a novel and as such none of the standard ethnographic or historical bibliographies about Congo even mentioned it. To label the book as a novel made it in effect invisible to historians or social scientists. Indeed to my knowledge it turned up only once in a little known wartime general bibliography of Congo as part of a set of 122 French and Dutch novels. ${ }^{3}$ Nor did the work become noteworthy as

${ }^{1}$ Ben Yagoda, Memoir: A History (New York, Riverhead Books, 2009), especially $244-271$.

2 Alfons Vermeulen, De pioniersdagen van Chicongo: Een verhaal uit het pioniersleven in den Congo (Amsterdam, Scheltens en Giltay, n.d. [1933]). Co-published in Belgium by De Sikkel, Antwerpen.

${ }^{3}$ Christian Monheim, Congo Bibliographie (Antwerpen, Veritas, 1942), 180-183. 
literature. When it appeared it was reviewed like other run-of the-mill novels by the rare standard literary journals in the Netherlands (dismissive) and in Belgium (appreciated). It sold about as well as most other novels. ${ }^{4}$ And, alas, like the other novels, it was soon forgotten. In any case, until recently neither historians, nor social scientists concerned with Africa bothered with novels. So it was not until I systematically began to read this kind of literature as part of the colonial record that I finally stumbled across it.

Despite the rather conventional love story at its core, I realized almost immediately that this book was "a find." To a large extent this novel seemed to be a crypto-autobiography, a memoir in hiding. The plot tells the story of a very young Dutch man hired as an agent by a trading company in Rotterdam and sent to the Independent Congo State. Soon after his arrival at headquarters in Brazzaville he is assigned to their factory at Luebo in Kasai. There the local manager provides him with a concubine and packs him off into the bush to the fledgling factory of Ibanche [Ibanc]. The hero immediately falls in love with his African consort and leads an idyllic life at the station where he, his love, and his factory all flourish. But, alas, a few years later his beloved dies in childbirth. He is devastated, resigns, and leaves Ibanche.

What struck me in all of this was the apparent accuracy of most details throughout the work. The company in Rotterdam could only be the NAHV (Nieuwe Afrikaansche Handels Vennootschap) and it did have a factory at Ibanche. His descriptions of landscapes and people seem to correspond to reality; his rendering of words in African languages, albeit garbled, is recognizable and the translations are usually correct; toponyms for the villages in a wide swath around Ibanche are genuine; and although his chronology is hazy it corresponds in general to what happened in the area during the years before early November 1904 when the factory was destroyed. Moreover no other known source contradicts anything in the book - if we accept that he uses pseudonyms for the colonial s he portrays. Therefore it looked as if, irrespective of the plot itself, all this information was trustworthy historical evidence and it did not seem to matter much whether the whole plot was true or not. Indeed the most reasonable explanation for all his local knowledge was that the author had really been a trader in Kasai around the time in question.

Yet I could not find anything out about this man except that he published a second novel entitled De Ingang der Hel [The Entrance to Hell] in 1938. That featured the same hero as a trader active at a later time in

${ }^{4}$ The whole edition (4,000 copies) sold out. See papers of Alfons Vermeulen to be deposited at Expatarchive: http:/www/welcome@xpatarchive.com. On this point see "Boekrecensies, Chicongo" and "correspondentie, uitgevers, Scheltens en Giltay." I am very grateful to Fred Th. van den Hoek who made these papers and his forthcoming edition of the Memoires available to me at www.Chicongo.nl. 
forests that now form part of the Central African Republic. ${ }^{5}$ In this work he even mentions that formerly he had been a trader-explorer in the parts of Kasai mentioned in his earlier book and he then tells the reader the following (page 6 and page 8):

\begin{abstract}
The romantic tale described in this book is not a phantasy, it is a bit of pioneers life and even though I have had to move some events and places elsewhere to shape this as a coherent story, these events are true... be it then a phantastic reality, but they are reality. In an earlier one of my works [and here he cites Chicongo's pioneering days in note] I described the institution of human sacrifices among the Babuka [sic]... (...) What I described then was also true, although the reality was actually even a bit more gruesome, for I have the good habit, as far as possible, to disguise the worst.
\end{abstract}

In a nutshell he claims to have lived in Kasai and that his book about Chicongo is based on truth. But then, any historian wonders how believable such statements are and how trustworthy their author. ${ }^{6}$ Moreover, it was still at least likely that "Vermeulen" was a pseudonym. Although well aware of this handicap I still halfheartedly tried to find any trace of the author or his descendants on the internet but without any success.

Nevertheless the data from Chicongo were so rich and seemed to be so reliable that I finally decided to use some of them. Yet this information lacked precise dates so that I could not use it as a set of factual statements about events observed by a reliable witness. I had to remain less specific. In the end I only made use of the following items for a reconstruction of the period and the region: how Africans imagined Europeans in Europe to beat the time, a description of a village court and one of village artisans, an account of friendship and love between young European colonials and local Africans, a portrayal of a Kuba woman trader in action, and a report about the Kuba poison ordeal. ${ }^{7}$ Corroboration on each of these points was provided by other sources with two exceptions: the story of his friendship with a young Kuba man and the activities of local women traders. Obviously I made far less use of the evidence available in this book than I could have if I had known more about the author and his presence in the region.

However, the publication of Being Colonized achieved what I had been unable to do. Nine months or so after its appearance I was contacted by Fred Th. van den Hoek. His computer had linked the name - it was not a pseudonym! - of his great grandfather, Alfons Vermeulen, to the refer-

${ }^{5}$ Alfons Vermeulen, De Ingang der Hel (Amsterdam, Wereldbibliotheek, 1938).

${ }^{6}$ Yagoda, Memoir, 100-102 for a sample of the "this is a true story" cliché.

${ }^{7}$ Jan Vansina, Being Colonized, 38, 51-52, 55-57, 63-65, 92. 
ences in my book. He informed me that his ancestor had left an almost ten inch high stack of typed pages of drafts for his nearly completed memoirs about his life in both Congo's as well as some other personal papers. ${ }^{8}$ He was preparing them for publication and would be glad to gain more information on the local context. This resulted in a fruitful mutual collaboration between us. One of the results was that a cornucopia of information became now available with which to assess the reliability of the Chicongo book and the credibility of its author.

\section{Alfons Vermeulen and the Writing of Chicongo}

Alfons Vermeulen was born in Breda on 28 February 1877 and died there on 20 July 1965. Nominally a Roman Catholic he became disaffected as an adult and when he died he was buried in the Protestant cemetery at Breda. ${ }^{9}$ He grew up in a well educated family, and graduated from a prestigious category of high school (H.B.S.) where he was given a solid liberal education that included among others French, German, English and even some Latin. In later life he read a good deal including specialized professional discussions by anthropologists and others knowledgeable about the denizens of Equatorial Africa.

Four years after graduation, on 17 October 1899, he signed a three year contract with the Nieuwe Afrikaansche Handels Vennootschap (NAHV) in Rotterdam to work as an agent in one of the two Congos. The only unusual feature about this enrollment was the level of his education for at the time most government or commercial agents in Equatorial Africa only had a grade school education. He remained in the Independent State of Congo until circa May 1904, first for the NAHV and then from May 1902 for the Compagnie du Kasai. Then between October 1905 and 1908 he became a manager for the Compagnie de la Lobaye in the then French Congo. ${ }^{10}$ In 1908 he returned to the Netherlands where he married and where he seems to have stayed most of the time until 1912 according to family documents, although he maintained later that "between 1904 and 1912 he had been in the French Congo." Late in

8 The Vermeulen papers will soon be stored at the expat archive at The Hague. For the memoirs, see Fred Th. van den Hoek and Alfons Vermeulen, De Memoires van Chicongo: Episode uit het Afrikaanse Pioniersleven van Alfons Vermeulen, Factorijhouder voor de NAHV in Congo [The Memoirs of Chicongo: An Episode from the Pioneering Life in Africa of Alfons Vermeulen, Factory Manager for the NAHV in Congo], forthcoming.

${ }^{9}$ His second wife - tamily name Benkemper - was also buried there. She seems to have been Protestant, which would explain the situation.

${ }^{10}$ The novel Entry to Hell is based on this tour of duty.

11 For his declaration, see Alfons Vermeulen's papers, "Correspondentie Ridderorde, declaration of 11 April 1929." 
1912 or early in 1913 he signed up again for NAHV. From then on until his return home in May 1931 he worked for the company in the equatorial forests of the Belgian Congo, with an interruption between 1925 and 1928 when he traded copal in Amsterdam.

After May 1931 he remained in the Netherlands for the rest of his life as a businessman. In the thirties he also wrote and published his two novels, De Pioniersdagen van Chicongo: Een Verhaal uit het Pioniersleven in den Congo, in 1933, and De Ingang der Hel: Episode uit het Afrikaansche Pioniersleven, in 1938. By the time that book was published he also seemed to have started on a third novel as hinted by the conclusion to De Ingang. "That would become a book on its own. Perhaps Chicongo will tell me that next time." 12 But World War II intervened. Shortly thereafter - if not already during the war - he began to write memoirs and continued to work on them until 1963.

Chicongo, his first novel, seems to have been written in the Netherlands and relatively quickly between the second half of 1931 and the spring of 1933. It is not likely that he wrote any part of it earlier than that because he himself tells us in his memoirs that as manager, he simply had no time left for anything but work. ${ }^{13}$ The very idea of writing a book probably did not even enter his mind until the 1920s when he became a divisional manager at Coquilhatville. Then he may well have toyed with the idea of writing a book in his forthcoming retirement. At that time early colonials from Independent Congo days were revered as pioneer $s$ and heroes by their successors and he could claim to be one of them. As the mention of his knighthood in the order of Leopold II on the title page of the novel indicates, he was quite sensitive to this kind of recognition: telling his story was one way of achieving this. ${ }^{14}$

However he also had a social agenda. Thus he felt the need to defend the reputations of African consorts against the prejudices of people like the European ladies at Coquilhatville, but his most bitter indignation was

12 The very long chapter 12 of the Memoires is probably the main remnant of that third novel. Its story line follows on that of the second one and the following passage sounds very strange in the framework of memoirs. "For this is not a story of imagined tropical romance. In many ways it is rather a valuable documentary about the lives and the suffering of the first White agents at the time of the EIC" (Van den Hoek and Vermeulen, Memoires, chapter 12, "The motivation of Alfons"). In addition, this chapter deals with French Congo, not the Independent Congo.

${ }^{13}$ Van den Hoek and Vermeulen, Memoires, Chapter 7 (administrator); Vermeulen, Chicongo, 233 but it is obvious that he had quite a bit of free time e.g. to go hunting for birds.

${ }^{14}$ By 1929 he was hoping for that knighthood in the Order of Leopold II and it was awarded soon thereafter. See Alfons Vermeulen's papers, "Correspondentie." His mention of pioneers in the subtitles of both his novels is also striking. 
directed at the derogatory epithets such as "savages," "kaffirs," etc., by which the Dutch referred all too often to Africans. He probably acquired that disposition long before his return in 1931, as it seems to be linked to his experience after his return home in 1908. But by 1931 the obligation he felt to denounce such attitudes was overdue. Now he wrote: "But all of this pure nonsense (...) And therefore the author has to redress something and he will try to do this, because he likes his 'savages' too much."15

The book was to be a novel rather than a memoir. At that time memoirs were not fashionable. ${ }^{16}$ With the exception of authoritative senior public figures or celebrities very few people wrote them. It would be far too pretentious for someone like Vermeulen to even try his hand at this and anyway who would publish him? Hence why those who wished to tell their experiences turned around this obstacle by writing a novel, and there were plenty of precedents available in what was then known as "colonial literature." 17 Vermeulen's decision to go ahead, was clearly inspired by the example of others who had done exactly that after their return from the colonies. Since high school days he had known the Dutch iiterary classic Multatuli's Max Havelaar, a protest novel about colonial Java, published in 1860 as well as other works by the same author. He also knew Henri van Booven's Tropenwee [Tropical Misery], if only because Van Booven, like him, had been an agent for the NAHV. ${ }^{18}$ The man had left for Congo in 1898 a little over one year before Vermeulen's own departure. He contracted malaria on arrival, and had to be repatriated in early 1899. Van Booven's introspective novel became such a literary success in the Netherlands that it went through eighteen reprints. His example may have encouraged Vermeulen to take the plunge. Perhaps he fancied him-

15 Chicongo, 254. See also 228-229, 249-251 (about African consorts); 253-280 (about "Savages").

16 At least in French or in Dutch. For the situation in the United States and Great Britain, see Yagoda, Memoir, 143, 191-214. It is worthy observing that there were not enough of them yet for even Yagoda to set up a special category "colonial memoirs." The only memoir from colonial Africa he does mention is Isak Dinesen's Out of Africa.

${ }^{17}$ Monheim, Congo - Bibliographie has no rubric "Memoirs;" the rubric "Novels concerning Congo and Black Africa" lists forty-four items published before January 1931 (page 180-183). It is striking to note that Vermeulen seems to be the only author in this section who had been a trader.

18 Henri van Booven, Tropenwee (Amsterdam, Maatschappij voor goede en goedkoope lectuur, 1904). In his $\mathrm{De}$ Ingang der $\mathrm{Hel}$, on page 267, Vermeulen mentions "Tropenwee" and seems to mock its author as a useless sissy, while one subtitle in his Memoires mentions Commander Kurtz in a subheading of Chapter 12. Thereby he alludes there to the most famous introspective work of all, Joseph Conrad's Heart of Darkness, as well. Heart of Darkness was first published in bookform in 1902. 
self as a future writer as well. Be that as it may, however, he did not have any use for introspective novels as exemplars, but simply followed the pattern of run-of-the-mill romantic adventure stories. His plot was as stereotypic as any such novelette: a daring voyage out to the tropics, the discovery of perfect love, romantic bliss, and the ultimate tragedy.

The manner in which Vermeulen wrote his Memoires is well known and all indications are that his Chicongo novel was composed in a similar way. One must keep in mind that he was not a professional writer. His previous experience of writing had been limited to the composition of business reports or letters: composing a whole book was a different enterprise altogether. The organization of his text betrays this lack of experience especially by the irregular length of his chapters, which range from six to fiftysix pages. ${ }^{19}$ The surviving drafts for his Memoires tell us exactly how he composed them and he clearly used the same approach for Chicongo. Most likely he applied what he had learned about writing in high school since that had been his only experience of creative writing. Be that as it may, he wrote a separate composition for each topic he wanted to discuss, strung them together by association, and only later assembled them into chapters. The shortest chapters covered just a single topic but the longer ones consisted of several compositions that had been cobbled together. Despite the efforts of his editor at the publishers some traces of this way of writing survived. The most visible ones are that his main argument is often interrupted by almost irrelevant incidental remarks (obiter dicta), that there are repetitions, and that the transition from one topic to the next one is not always smooth.

Implicitly the book is composed of two parts. The first seven chapters detail the hero's progress from Europe to Ibanche and there was no problem of sequencing his topics in that part. But the structure of the second part (chapters 8-17), is much less obvious. He apparently distributed his topics first more or less haphazardly according to subject, then arranged them into two rough chronological sets and then put them in chapters. If we ignore the division into chapters and merely list the main themes of this second part in order of the number of pages he devotes to them we find these themes to be: the hero's factory, his family life with his African consort, and a defense of "primitive" African cultures against the accusation of savagery.

Most of the content of the book stems from his episodic memory, that is the remembrance of episodes in a person's life that establish his or her identity. From the mental master narrative of his self identity he chose

19 However, the shortest chapters are "notes" (according to their titles) and Fred Th. van den Hoek notes that they were either intended as articles for a literary journal (there is some evidence for this) or as a long note at the end of a chapter. 
episodes of interest to his potential readers that also reflected well on himself. These include reminiscences to back up his expressed opinions about Africans against what he perceives to be deleterious but common prejudices among his expected readers. From his choices and the opinions he expresses it is obvious that he was an ardent colonialist, but one who was ambiguous about the supposed benefits of civilization (not surprising in the 1930's) and indignant about the general disdain of Africans, even though on the other hand he shares many clichés about them with his fellow colonials

But he also consulted some of his own documents and photographs to assist and refresh his memories. In his Memoires he paints the following nostalgic picture:

\begin{abstract}
Copies of old reports, and well thumbed, sometimes even moldy notebooks and memoranda lie on my writing desk (...) they still radiate the mysterious light of the African primeval forest. They are for me precious memories from the most beautiful time in a genuine free masculine way of life (...) over there, many years ago, some are more than half a century old (...) now all of that is endlessly far away, never to be relived again by anyone (...) I repeat it again, when Africa still was the old mysterious Africa. Here [in this book] I grab only a fistful of the many annotations in which I wrote down remarkable features and strange expressions. ${ }^{20}$
\end{abstract}

We also encounter a few casual references to notebooks in his novels as well. The most elaborate occurs in The Entrance to Hell where "in an old well-thumbed notebook of Chicongo" he actually cites such an annotation once. The citation consists of a few sentences about a whole string of burned out villages along a road near the Lobaye river in French Congo. ${ }^{21}$ He seems to have used these reports, notebooks, and old photographs primarily as cues to recall long-forgotten memories or to flesh out half remembered events as he tells us elsewhere. ${ }^{22}$ Unfortunately, once he had written the compositions for which he used them, he apparently destroyed

20 Van den Hoek and Vermeulen, Memoires, chapter 12, section "Nog een Memoire." This sort of vignette is also a cliché in the genre, although I believe that in this case it is a true description. Unfortunately he apparently destroyed all these documents after composing his drafts because his heirs found none of these among his papers.

21 Vermeulen, Entrance to Hell, 229; for a more casual mention of a notebook Vermeulen, Chicongo, 187.

22 For an example see Van den Hoek and Vermeulen, Memoires, chapter 12, section "Vrouwen stelen niet." He had jotted down the saying "women do not steal" in his notebook to ask his head capita about this, but he forgot to do so, "and now, so many years later, I am perusing the same booklet and find this wise native saying again, that set me thinking at that time." 
the old notebooks and other reports, for none were found among his papers after his death.

The remembrance of other episodes in his work seem to have been triggered by books he read about Africans and whose arguments he approved of or rejected. In any case from time to time he backs his own opinions in Chicongo with all the authority of an old-timer by citing a string of reminiscences from his days in Ibanche. ${ }^{23}$

\section{The Memoires and Chicongo}

The drafts of Vermeulen Memoires greatly affect our assessment of the reliability of Chicongo. First, as we saw, they give us a key to its composition and provide a convincing explanation for its formal and stylistic peculiarities. Secondly they add a substantial amount of information to the data in Chicongo, and when they rephrase passages already known from that book, they throw more light on the working of Vermeulen's memory or on his new writing intentions. The Memoires add about 64,000 words concerning the author's experience at Ibaanc to the 80,000 in Chicongo or about four fifths of what existed. Even though the professed intent of the two works is quite different, still the contents of the Memoires' chapters 6, 7, and 13 substantially overlap with those of chapters $8,9,12,14,15$ of Chicongo. That is particularly so for Memoires' chapter 7 "The Quiet Factory in the Bush," Chicongo chapter 8 "Ibanche on the plains," and chapter 14 "Life at the Factory."

One goal of such comparisons is to spot the differences between the old and the new versions to see whether they contradict each other or not. Also, some unexpected insights do turn up sometimes. A small example of this is the statement about the place of origin of the Bushong. This occurs as an aside both in Chicongo, page 222, and again in Memoires, page 77. In Chicongo a description of the imposing figure of Mikobjé, an old Bushong warrior, leads the author to muse by association about their origins and that aside then leads to a discussion of a trade in cowries. In Memoires, the antiquity of the use of cowries, which the Bushong supposedly brought

23 This is the dominant feature in Chicongo, chapter 15, 253-280. In his Memoires he does mention some authors by name but we cannot assume that he had actually read their books before 1931, even if they had been published well before then. Thus his discussion in chapter 15 on the religious beliefs held by Bantu speakers $(255-258,269)$ seems to be based on A. LeRoy, La Religion des Primitifs (Paris, Gabriel Beauchesne \& Co., 1909). He had met Monseigneur LeRoy personally when he was in French Congo and probably did read his book soon after it was published. Further along his reference to "pygmy religion" is very probably based on the works of Henri Trilles regarding Gabon and not on those of Paul Schebesta who only began his research in Ituri in 1929. 
from their land of origin, leads into the same aside. Chicongo, page 222, has:

According to the legend current among them they came from the vicinity of lake Chad on the border of the Sahara. With only a handful of men they fought their way across Africa. They crossed seven rivers before they settled in the lands between the Lulua and Sankuru rivers and subjugated the surrounding tribes, until they finally suffered their first defeat at the hands of the Sappo Sap, led by Mulumba N'Kusu, the father of Mulèkedi [his African consort].

Memoires, page 77 , has:

The Besjongo told me that they had not always lived in the land between the Lulua and the Sankuru. Long long ago they had come from the north, had crossed seven rivers while fighting, and they had named the main river in the area where they now live "Lutsjadi," in memory of a river on whose banks they had dwelled in earlier times. Very likely they referred thereby to the "Chari-river" which empties itself in lake Chad I believe. (...) From there they had already brought their specific currency, the cowry (...).

The most unexpected result from this confrontation is that this bit of information is not just a serendipitous or incidental comment after all. It clearly is a point the author is eager to make and the cowries or Mikobjé are only a convenient entry into the topic. Furthermore the discrepancies between the versions are instructive. Memoires makes clear that Lake Chad was not part of any oral tradition of the Bushong. Apparently the fighting, the seven rivers, and the direction of travel, were the only content of that tradition. The link between Lutsjadi and Chari obviously rests only on speculative etymology, again not from any tradition. Thirdly we stumble on yet another unexpected insight. There is some unattributed borrowing here. Either Vermeulen took the idea of Bushong origins in far away Chad from the publications (1909 and after) of the anthropologist Emil Torday or the latter borrowed it from Vermeulen. We will return to that issue.

Once similar and complementary passages in both books have been compared we can combine them together and thus enrich our understanding of events or situations. That increase in understanding usually occurs because the combination of information often enlarges its context to the point that it changes the meaning of the data in Chicongo, even though most of the time such a "context-effect" remains fairly limited. Thus we are told in both works how the manager recruited a number of young boys to hawk sea salt in exchange for cowries in the villages. But it is only in the Memoires that we learn that he did this because cowries were too expensive to buy abroad, and yet were the essential currency in trad- 
ing with the Kuba. The NAHV company imported them at a stiff price in thirty kilogram boxes from England, but it was much cheaper to have the boys buy cowries back from Kuba women in return for sea salt from Sal in the Cape Verde Islands. That these village women were comfortable with the idea of buying salt from young boys has to do with the initiation of Bushong boys. During this process the latter were wont to go on an expedition to make salt in the marshes "far" east of Ibanche and to give the product to their mothers at the conclusion of the ceremonies as proof of their derring-do. ${ }^{24}$

Yet sometimes the new context alters the picture more radically. In Chicongo there is no mention at all of any mission stations, yet there were mission stations of the American Presbyterian Christian Missions (APCM) at that time in Luebo and in Ibanche. They are mentioned in Memoires. There we also learn that Vermeulen, the Dutchman, detested both the English and the Americans because of the Boer War and also because of their supposedly condescending airs. We further learn that his caravan once had a fight with the workers of the mission station of Luebo. Elsewhere in the same book he also tells us to that he liked William Sheppard, the African-American missionary then stationed at Ibanche, but thought that his white colleagues from Luebo exploited him. The overall effect of this new information, however, is to destroy the idyllic atmosphere of Chicongo and to warn us that something is truly amiss with the overall tone of that novel.

Which brings us to the ultimate major point of a comparison between the two works. It brings out the respective impact of the different aims pursued in either book. The idyllic atmosphere in Chicongo is required for the love story in the novel and leads to the deliberate omission of most social tensions in the novel, just as it also leads to the deliberate rejection of all reminiscences involving violence related to the production of rubber, even to the point of omitting the murder of two of his agents in far away villages. Such incidents deserve a place in Memoires with its emphasis on how the lone company manager had to rule over a large territory bereft of all official law and order. On the other hand the novel does describe and attempts to justify his own violent outbursts against his workmen and that seemed at first to me to indicate that he was not shying away from the topic. Hence I did not expect the total erasure of all references to serious violence beyond his factory in Chicongo and this misled me. It is easy to remark now that I lacked critical distance to the novel, even though I compared it systematically to all other known sources. But in fact

24 Jan Vansina, "Initiation Rituals of the Bushong," Africa 25 (1955), 138-155. Any anthropologist will note that this activity impacted on operations ranging from the Maldive Islands, to London, and to the Cape Verde island of Sal. A global world of commerce already existed at the time. 
there was no way I could have known this and the episode underlines the increased risks one takes in relying on negative evidence (no violence) from a work of fiction.

As a result the contrast I drew in Being Colonized between the peaceful character of the trade before 1902 when various commercial companies competed with each other and the violence that erupted once the monopoly of the Compagnie du Kasai was established was somewhat overdone even though that contrast was actually underlined by other sources at the time. ${ }^{25}$ True all the violent incidents mentioned in Memoires may well have occurred after the take-over by the Compagnie du Kasai in May 1902, but it is definitely possible at least that a murder linked to the rubber trade in a far away village had occurred earlier. After all, the practice of giving advance credit to commercial practices that often led to outbursts of violence in remote villages after 1902, already existed to some extent well before then.

In the end one may well wonder why the tone in the two accounts of the same author written twenty and more years is so different. True one was a novel, the other a memoir, and hence their aims were not the same but one suspects that this only answers the question in part. Another substantial reason for that difference seems to result from the huge change in the Zeitgeist, the atmosphere between the early 1930's when Chicongo was written and the earlier 1950's when nearly all the basic drafts for the Memoires were written. Around 1930 colonies flourished and pioneers were much revered in colonial circles, so that a pioneering trader could be honored, whereas after 1940 Europeans first experienced previously unimaginable horrors until 1945 and then the Netherlands lost their Dutch East Indies in 1949. Public opinion there, and particularly the leadership of the largest party, the labor party (Partij van de Arbeid), reviled and despised colonials. ${ }^{26}$ In post-war Belgium a good portion of the public shared such feelings. And yet at the same time the old prejudice that Africans were savages flourished still as much as ever before. It is not surprising then that Vermeulen judged after 1945 that the time had come for blunt language and hence for a memoir rather than novels. At the same time the Zeitgeist explains why his discourse then becomes quite defensive, and from time

25 Vansina, Being Colonized, 61-63, 86-93. Awareness of the contrast at the time was widespread. On this issue see particularly the answers of the magistrate Bossolo to eight questions asked by the official commission of enquiry, A.M. Delathuy, $D e$ geheime documentatie van de onderzoekscommissie in de Kongostaat (Berchem, Uitgeverij EPO, 1988), 44.

${ }^{26}$ The Partij van de Arbeid founded on 9 February 1946 was responsible for the creation of the welfare state in the Netherlands. Vermeulen seems to have been particularly riled by the policy statements of one of its first leaders, probably Koos Vorrink. He also associated the party with one of its predecessors, the pre-war pacifist SDAP (Sociaal Democratische Arbeiders Partij). 
to time even bitterly polemical. Yet the Memoires, we are told in its prefaces, were still written to fight that infamous prejudice about savages. ${ }^{27}$ Nevertheless, they also indignantly refute public accusations that colonial traders had only been exploiters and wild adventurers and they argue instead that the early colonial traders were actually the principal harbingers of the benefits of modern life and thus benefactors of the local Africans. ${ }^{28}$

As observers today we cannot fail to come to the conclusion that the Zeitgeist greatly influenced all of the author's works, be they novel s or memoirs. To give but one example of this: whereas the absence of the English speaking APCM missionaries in Chicongo flows from its romantic character, one suspects that their appearance as an undermining force in Memoires has just as much to do with his bitterness about the role of the UK and the USA in the loss of the Dutch East Indies after 1945 than with the accusations of English or American missionaries during the Congo Reform Campaign. ${ }^{29}$

Such a forceful imprint of the time when they are written on narratives about the past is quite familiar from the debates about the trustworthiness of oral tradition and oral history. In consequence much of what these oral testimonies have to say is often wholly discounted as evidence. Yet the same situation prevails for written narratives about the past as well, be they novels, reminiscences, or memoirs. Should such texts also be discounted as evidence to the same extent? Should written and oral data not be treated in exactly the same way on this point? Actually the correct solution is again to assess each individual source separately on its own merits, rather than dismiss all of them out of hand as tainted merchandise.

27 Memoires, "Voorwoord" and "Preface." In the latter he states that his goal is to show that while White People claim to be civilized they are morally not more elevated than Black People and hence that "savages" do not exist. The impact of World War II on this line of reasoning is obvious. Note, however, that near the end of the long Chapter 12, "De motivatie van de schrijver" [The motivation of the author] in a passage lie later scrapped he added a paragraph after his denunciation of "savages," to the effect that he writes his memoirs for his "own satisfaction: Once again I experience all of this in my old age, having forgotten the misery of it all long since while the beauty, the interesting aspects of it have remained with me."

28 Van den Hoek and Vermeulen, Memoires, especially chapter 7, the polemic in the section "Adventurers and exploiters," and chapter 12, "Roving knights in the African wilderness." By then Vermeulen had also suffered from a set of cutting negative and rather blinkered reviews of his two novels in the Netherlands.

29 Van den Hoek and Vermeulen, Memoires, chapter 6, "The Riff-raff or the Ruga-ruga of the Whiteman," first section. Especially footnotes 38 and 39 where he reminds his Dutch readers of the Boer war. 


\section{Assessing the Credibility of Chicongo Today}

The recovery of papers and especially of the drafts for the Memoires has completely altered the situation. We now know for certain who the author is, all the pseudonyms can be deciphered, and we can date all events to within a year or so. All of this turns the narratives in the book from fiction into remembrances that can be exactly placed in the whole context of all other sources. They are now statements to which the rules of evidence can be applied. Nevertheless there is more to it than this; the literary genre does matter and the fact that Chicongo is a novel rather than a memoir has consequences.

The most glaring among these is how the overall plot of the novel distorts reality. First the portrayal of the hero is not that of the author but of an idealized version of the author. The hero is a little younger than Vermeulen really was, his service as a lowly clerk in Brazzaville is downplayed nearly to the point of oblivion while most of the time spent there is added to the hero's time at Ibanche. The manner in which he acquired his African consort is made considerably more acceptable to his readers than the reality had been. He either bought her as a slave or as a free child in the household of a notorious slaver. His hero boasts of his fluency in the local languages, but in reality Vermeulen only acquired a very rudimentary form of Tshiluba, a smattering of words in Bushong, and even less in other languages. ${ }^{30}$ Apparently his overseer, his wife, or someone else in his household usually interpreted for him, whatever the language, with the only exception of rudimentary Tshiluba. That particular situation obviously affects the reliability of many passages in the book. Thus the author's delusions on this point leaves the casual reader of Chicongo almost wholly unaware that Vermeulen owes much of his knowledge about Bushong village life to Luba speakers among his own personnel who themselves often had it by hearsay from Luba speaking slaves of the Bushong. In particular rumors carried by slaves fleeing fom the Kuba capital were probably the source of all the sensational and unreliable information about royal burials and human sacrifices in all of Vermeulen's books. 31

${ }^{30}$ Vermeulen, Chicongo, 108 (learning the language), 143, 162; Van den Hoek and Vermeulen, Memoires, chapter 12, "Advantages of speaking the language" (boasting). His transcription of Bantu sentences he heard as well as his explanations in Memoires, chapter 6, "The lesson in the Bantu language," show that he had not even truly grasped the basic rule of prefix concordance.

31 Vermeulen, Chicongo, 268-269; Vermeulen, Memoires, chapter 13, "The institution called Beloke," section "The funeral of king Misjapé." Not only was much of this sheer fantasy - although there were some human sacrifices - but even the name of the king mentioned was wrong. King Mishaape died in July 1900, not in 1902. See Vansina, Being Colonized, 75-79. A similar situation obtained at the APCM missions so that nearly all the available written sources suffer from a very strong Luba bias. 
Vermeulen also sacrificed true chronology to the necessities imposed by the plot. Novels abhor dates and go to great lengths to avoid them. If they cannot do so they will express them indirectly as $\mathbf{x}$ time later or earlier than a set point in the narrative, Moreover, Vermeulen willfully deviates from the truth in order to suggest that his hero arrived about a year earlier at Ibanche than he himself did. The result is that the chronology of the novel is so vague and apparently contradictory that it has proven necessary to straighten it out by finding dates attested by others. ${ }^{32}$ Now it is known that he left for Congo very soon after signing his contract in Rotterdam and passed through Kinshasa on 29 November 1899 on his way to headquarters in Brazzaville. There he worked as a lowly clerk while he learned the trade. ${ }^{33}$ On 21 June 1900 his superior wrote to the direction in Rotterdam that Vermeulen was too uncouth to stay at headquarters and had been sent to Luebo in Kasai. There he may have stayed only around one month to become familiar with local business practice, before he was dispatched to Ibanche (Ibanc), probably in late January or early February 1900. A few months later, perhaps in April or May, he took over as manager there. ${ }^{34}$ On 24 December 1901 all companies operating in Kasai, including the NAHV's factories there merged into the new Compagnie du Kasai. Hence, Vermeulen and his factory were formally integrated into that company either on 1 May 1902 or in September of that year. ${ }^{35}$ By 5 October 1903 he had tendered his resignation to the company, but it had not yet been accepted. He seems to have only handed the factory over to his successor in March 1904 and to have left Congo in May. ${ }^{36}$ With this information it is now possible to date most episodes in Chicongo to within about six months.

Just as pervasive and more insidious than the idealization of the hero and the manipulation of the chronology is the idyllic atmosphere of life at

32 The following dates stem from NAHV and CK documents in Vermeulen's papers.

33 See Alfons Vermeulen's papers, "Andere Publicaties - Stadsgenoten," no date/probably 1950's. He obviously did not like this "komis" job ["commis" in French] and was not suited for it.

34 These dates are calculated by dead reckoning after (31 January 1900) Vermeulen's own testimony that he stayed one month in Chicongo, his testimony about his trip from Luebo to Ibanche during the short dry season (Vermeulen, Chicongo, 114). A NAHV document at headquarters that lists him still as an agent at Luebo on 16 May 1901 is probably out of date

35 We do not know which date is correct: 1 May according to the NAHV records, or September according to Vermeulen's declaration of 11 April 1929 in his papers "Correspondentie Ridderorde, 11 April 1929." This discrepancy still remains to be explained.

36 See Alfons Vermeulen's Papers, "Correspondentie-Compagnie du Kasai," and "Correspondentie Ridderorde." 
Ibanche he required by the plot. As we have seen some major incidents of violence related to the rubber trade in the region are even wholly omitted when they concern loss of life. Indeed by omitting any reference to the American missions in the region, even at Ibanche, Chicongo avoids the whole topic of atrocities and the Congo Reform Movement. Such a slant in the choice of reminiscences is not easy to spot because it can only be detected by the complete absence of any mention of events or situations expected to be present on the basis of other evidence. Thus in this case the critical reader would expect mention of the missionaries and note their absence from the narrative, but the same reader would not suspect anything about murders by others in outposts far away because the novel does describe violence initiated by Chicongo against his own personnel. That was actually completely unexpected.

These then are the major distortions that affect all parts of Chicongo. They are largely absent in the Memoires, although Vermeulen continues to have too good an opinion of himself, his talents, and the social benefits for all of his profession and although he also continues to lie about the date of his arrival in Africa, obviously for a compelling practical reason that already existed in 1904 but that remains unknown to us. ${ }^{37}$ His selection of remembrances are now dictated by the goal of each chapter. Here the pre-eminent theme of the chapters about Kasai is the factory and its management and much of the information they contain is either new or complementary to that from Chicongo.

Besides these general features, however, specific passages both in Chicongo and in Memoires contain occasionally errors of fact or misinterpretations of which Vermeulen himself was often unaware. Most of these result from biases of his interpreters and occasional misinformation due to cultural misunderstanding. The two sources of error often go together. For instance the essential information given about Bushong village government is reliable even though it is incomplete but it is marred by misunderstanding. Thus the titles of the main notables are correct and their list is valid, but he does not understand their roles and casts them in familiar Dutch functions such as "communal lawyer" or "communal process server." ${ }^{8}$ Fortunately most biases of this sort are easily detected.

37 He claimed to have first arrived in Congo in May 1898 more than a year earlier than he did. The earliest known document in which this date is presumed from the calculation of length of service comes in a letter from 1903 about his pending resignation written by his friend and supervisor (Alfons Vermeulen's papers, "Correspondentie Compagnie du Kasai"). His own letter from 1929 with a chronology related to the pending award of a knighthood makes the claim explicit ("Correspondentie Ridderorde").

38 Vermeulen, Chicongo, 260; Van den Hoek and Vermeulen, Memoires, chapter 13, section "The visit of the village headman and the council of Bongamba." 
Vermeulen did not borrow any factual information from other expatriate writers, with a single possible exception: the puzzling passage about the Bushong legend concerning their origin from lake Chad and their migrations across seven rivers to arrive in the land where they live now. Not only was the link with lake Chad merely etymological speculation as is evident from Memoires, but the same claim had already been made in the publications of the anthropologist Emil Torday as early as 1909 and several times later on. Torday visited Kuba country in late 1908 four years after Vermeulen had left. Two years later his publications were already the standard academic authority about the region. His assertion was exclusively based on the perceived etymological similarity between the names of the Sankuru and the Chari rivers, later reinforced by an argument about the distribution of throwing knives. ${ }^{39}$ Did Vermeulen copy Torday's reasoning in Chicongo without any acknowledgment? Was he perhaps inspired by a text about Kuba origins derived from Torday in a museum display? Yet this is not a case of straightforward plagiarism because of a major and puzzling discrepancy in the etymologies used by the two authors to make their case. One would expect such kind of discrepancies in oral but not in written sources. ${ }^{40}$ Hence it is not to be excluded that it was Torday who borrowed Vermeulen's insights. After all, like Vermeulen, Torday had been an agent of the Compagnie du Kasai, before he started on his expedition and one or other fellow agent of the company might have told him earlier about Vermeulen's speculation. Nevertheless a scenario in which Vermeulen took the basic idea from Torday but reshaped the etymology is just as possible. The only certainty remains that the two statements are not independent of each other.

\section{Conclusion}

One can conclude from all the considerations above that, on the whole, Alfons Vermeulen's statements are trustworthy, even if he, like so many people, exaggerates from time to time or rounds off his numbers. The literary requirements of the genre varnish reality in his novels (more so in Chicongo than in Entrance to Hell) but the Memoires appear to be more straightforward even though they also are quite opinionated. However, all

39 Vermeulen, Chicongo, 222; Van den Hoek and Vermeulen, Memoires, Emil Torday and T.A. Joyce, Notes ethnographiques...les Bushongo (Bruxelles, Document ethnographiques...Congo Belge, 1910), 43; Emil Torday, "Sankuru and Chari Land and Peoples of the Kasai Basin," The Geographical Journal 35 (1910), 26-57, 41 (claims is "history"); Emil Torday, On the Trail of the Bushongo (Philadelphia, Lippincott, 1925), 145 (throwing knife with etymology of Bushong!) and endmap.

${ }^{40}$ Torday, On the Trail, 145 relates the hydronym Chari in Chad to ncal (in his spelling chan) river in Bushong. Vermeulen links the hydronym Chari to the hydronym Lacwady (his spelling Lutshadi) in the Kuba kingdom. 
too often the man misleads by omission. So while one can accept most of his specific positive statements as reliable evidence, one should be wary of extrapolating from them even to conclusions he seems to suggest but does not actually spell out. Similarly one must also be quite careful to generalize from his specific statements.

And so this whole exercise in method ends with a pleasant surprise. Instead of being able to use some concrete data of Chicongo merely to confirm better documented evidence found elsewhere as was our practice before applying the rules of evidence, one now finds that all its concrete data can be used. In any case it does not make sense anymore to treat Chicongo in isolation since Memoires adds a good deal of solid supplementary information to the content s of the novel. As a result Vermeulen's corpus is suddenly catapulted from a minor source of social history to one of the four main bodies of data in this period for this area. ${ }^{41}$ The bulk of its data about Kasai concerns the factory of Ibanc, with a description of Bushong and Kete village life as a subsidiary theme. That by itself is even more of a pleasant surprise not just because Vermeulen is the only one among the few traders who have written about this period to focus on factory trade and all the facets of its commercial operations. ${ }^{42}$ So his data on this point are particularly valuable because they are unique. Finally, they are all the more precious because he describes the trading operations at a factory on the very eve of the moment that this nineteenth century type of establishment was being replaced by the very different kind of operations run by new concessionary companies like the Compagnie du Kasai. ${ }^{43}$

The results of our application of the rules of evidence to the Vermeulen corpus are striking indeed. How much richer and better is the evidence now compared to what we had before! Such a result is quite the opposite of the unavowed expectations of the all too many who still seem

41 The others are William H. Sheppard, Presbyterian Pioneers in Congo (Richmond, Pentecostal Publishing Company, 1917), the works of Torday already cited (1908) and various writings by Leo Frobenius (1905-1906).

42 Pierre Salmon, La carrière africaine de Harry Bombeeck, agent commercial (18961899) (Bruxelles, Civilisations, 1990) based on his diaries and letters is not actually focused on his business, but is typical for the published literature based on trader's papers.

${ }^{43}$ Only one other book about such an old style factory exists. This is Charles Jeannest, Quatre années au Congo (Paris, Charpentier, 1883). His "four years in the Congo" date from the mid-1870's and his factory was based on the northern coast of Angola. This can be directly compared to Vermeulen's factory. But the latter's focus on its commercial operations is much more intense than Jeannest's. For the style of business transactions at posts of the Compagnie du Kasai, see Leo Frobenius, "Kolonialwirtschaftliches aus dem Kongo-Kassai Gebiet; eigene Beobachtungen," Mitteilungen der Geographischen Gesellschaft in Hamburg, XXII (1907 [reprint in Erlebte Erdteile III, Frankfurt 1925]), 193-253. 
to think that applying the rules of evidence to recent historical documents is a pettifogging, negative, and destructive enterprise, and a waste of time. They are wrong: applying the rules of evidence often has a liberating effect, namely to allow the use of information that would otherwise have to otherwise be unacceptable.

\section{References}

Delathuy, A.M., De geheime documentatie van de onderzoekscommissie in de Kongostaat (Berchem, Uitgeverij EPO, 1988).

Frobenius, Leo, "Kolonialwirtschaftliches aus dem Kongo-Kassai Gebiet; eigene Beobachtungen," Mitteilungen der Geographischen Gesellschaft in Hamburg, XXII (1907 [reprint in Erlebte Erdteile III, Frankfurt 1925]), 193-253.

Jeannest, Charles, Quatre annëes au Congo (Paris, Charpentier, 1883).

LeRoy, A., La Religion des Primitifs (Paris, Gabriel Beauchesne \& Co., 1909).

Monheim, Christian, Congo Bibliographie (Antwerpen, Veritas, 1942).

Salmon, Pierre, La carrière africaine de Harry Bombeeck, agent commercial (1896-1899) (Bruxelles, Civilisations, 1990).

Sheppard, William H., Presbyterian Pioneers in Congo (Richmond, Pentecostal Publishing Company, 1917).

Torday, Emil, "Sankuru and Chari - Land and Peoples of the Kasai Basin," The Geographical Joumal 35-1 (1910), 26-57.

- On the Trail of the Bushongo (Philadelphia, Lippincott, 1925).

, and T.A. Joyce, Notes ethnographiques...les Bushongo (Bruxelles, Document ethnographiques...Congo Belge, 1910).

Van Booven, Henri, Tropenwee (Amsterdam, Maatschappij voor goede en goedkoope lectuur, 1904).

Van den Hoek, Fred Th., and Alfons Vermeulen, De Memoires van Chicongo: Episode uit het Afrikaanse Pioniersleven van Alfons Vermeulen, Factorijhouder voor de NAHV in Congo [The Memoirs of Chicongo: An Episode from the Pioneering Life in Africa of Alfons Vermeulen, Factory Manager for the NAHV in Congo], forthcoming.

Vansina, Jan, "Initiation Rituals of the Bushong," Africa 25 (1955), 138-155.

, Being Colonized, The Kuba Experience in Rural Congo, 1880-1960 (Madison, The University of Wisconsin Press, 2010).

Vermeulen, Alfons, De pioniersdagen van Chicongo: Een verhaal uit het pioniersleven in den Congo (Amsterdam, Scheltens en Giltay, n.d. [1933]).

—, De Ingang der Hel (Amsterdam, Wereldbibliotheek, 1938).

Yagoda, Ben, Memoir: A History (New York, Riverhead Books, 2009). 